\title{
REVISITING THE CLINE FROM CODE-SWITCHING TO BORROWING: EVIDENCE FROM THE LATE MIDDLE ENGLISH CELY LETTERS (1472-1488)*
}

\author{
J. Camilo Conde-Silvestre \\ Universidad de Murcia
}

\begin{abstract}
In this paper I examine the relationship between code-switching and lexical borrowing in the Cely letters (1472-1488). Most researchers agree in situating these concepts at the opposite ends of a diachronic continuum, so that code-switches, in the course of time and given the adequate circumstances, may become integrated borrowings in the recipient language. There is, however, some controversy as regards the classification of intermediate phenomena such as non-assimilated or nonce borrowings. Yuron Matras has recently proposed a set of criteria which, in my opinion, are useful to categorise the intermediate elements in the continuum. These criteria are applied to a selection of words from the Cely letters. As such, the analysis of these terms helps test the historical validity of Matras's benchmark, at the same time as it determines the necessity of keeping a distinctive terminology.
\end{abstract}

KeYwords: code-switching, lexical borrowing, non-assimilated borrowing, Cely letters, Middle English.

\section{LA GRADACIÓN DE CAMBIOS DE CÓDIGO Y PRÉSTAMOS: UNA RECONSIDERACIÓN A PARTIR DE DATOS PROCEDENTES DE LAS CELY LETTERS (1472-1488)}

\section{RESUMEN}

A partir del análisis del corpus de correspondencia medieval conocido como Cely letters (1472-1488) profundizo aquí en la relación entre cambio de código y préstamo léxico. Los investigadores está de acuerdo en situar ambos conceptos en los extremos de un continuo diacrónico, de modo que los cambios de código, en el curso del tiempo y en las circunstancias adecuadas, pueden integrarse en la lengua receptora como préstamos; sin embargo, hay discrepancias al abordar categorías intermedias, como los llamados préstamos no integrados o nonce borrowings. Yuron Matras ha propuesto una serir de criterios que permiten categorizar estos elementos intermedios en el continuo. La aplicación de estos criterios a una selección de voces extraídas de las Cely letters permite verificar su validez histórica a la vez que determina la prioridad de mantener las distinciones terminológicas.

Palabras clave: cambio de código, préstamo léxico, préstamo no integrado, Cely letters, Middle English. 


\section{INTRODUCTION}

In this paper I will delve into the trite relationship between code-switching and borrowing in the historical context afforded by the Cely letters: a well-known collection of 247 documents exchanged by this London family of wool merchants and their associates between 1472 and 1488. Most of the correspondents were probably monolingual speakers of English and, in fact, all the letters are written in this language, except two in French and one in Dutch. The following broad view of code-switching, proposed by Penelope Gardner-Chloros, is adopted as a methodological starting point: "the use of several languages or dialects in the same conversation or sentence by bilingual people. It affects practically everyone who is in contact with more than one language or dialect, to a greater or lesser extent" (Codeswitching, 4). This view-point also entails a broad approach to bilingualism as one end in the continuum extending from the ability to use two or more languages in different degrees, to pure monolingualism at the other, with a range of intermediate contours that may include a passive familiarity with the $\mathrm{L}_{2}$ (Thomason Language Contact, 30-32; Matras 111-112). I think this model properly fits the late medieval context of the Cely letters, when pure monolingualism was exceptional -as it is in the modern globalised world- and texts were "composed and received in a multilingual network of allusions, undergirdings, expectations, resonances" (Wogan-Browne 7; see also: Pahta 529).

As such, code-switching is often used as an umbrella term that can be applied to a range of language mixing and contact phenomena. A majority of scholars in the field have proposed to see all language-contact phenomena in a continuum, with code-switching -whose elements have "recognizable limits in the sentence or text" (Gardner-Chloros Code-Switching, 26) - situated at its centre, and other language mixing phenomena placed towards the extremity: "fused lects" -"stabilized mixed varieties," where the languages affected are integrated to such an extent that they form a single grammatical system instead of two separate ones- and "language mixing," where it is not the "individual switch points that carry significance but the uses of the overall switching mode" (Auer 309-322; see also: Gardner-Chloros CodeSwitching, 10-13; Gardner-Chloros "Contact...," 192; Pahta 529). At the other end of the continuum, code-switching leads into borrowing, since the latter is usually assumed to start "as spontaneous code-switches [...] generaliz[ing] themselves among speakers of the host language" (Gardner-Chloros Code-switching, 12; GardnerChloros "Contact...," 195; see also: Romaine 123-124; Thomason "Contact...," 694-696; Bullock and Toribio 2; Schendl and Wright 23-24). In between, other phenomena such as "non-assimilated (nonce) borrowings," "loan translations" (calques) and "semantic extensions" can be contemplated.

* Financial support for this research has been provided by Fundación Séneca, the Murcian Agency for Science and Technology (grant no. 20585-EE-18). This support is hereby gratefully acknowledged. 


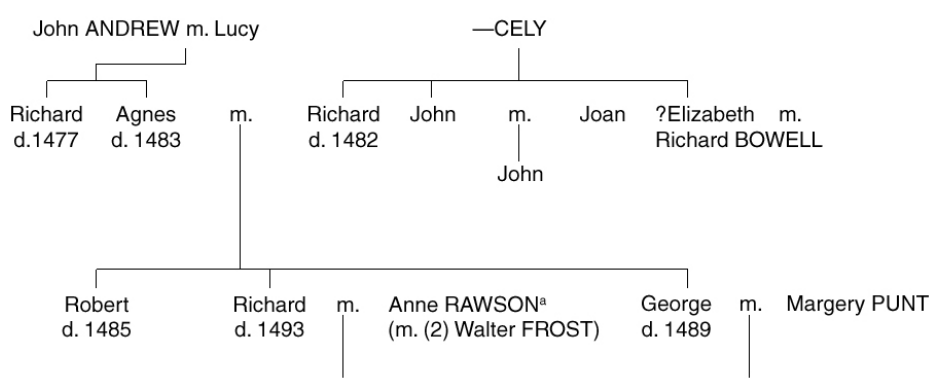

Figure 1. Core members of the Cely family: first and second generations (adapted from Hanham Celys..., 2).

\section{THE MULTILINGUAL BACKGROUND OF THE CELYS AND THEIR CORRESPONDENTS}

The Cely collection comprises letters written by members of the family and by people of different extraction related to them. As regards the Cely family, the eldest member is the London Merchant of the Staple Richard Cely the elder (d. 1482) (see figure 1). Most of his letters are sent to his son George Cely (d. 1489), when the latter was working at Calais, first as an apprentice and then as a factor. In 1482, after his father's death, he moved to London, where he married Margery (in May 1484) and took over the responsibility of the family business in partnership with his brother Richard Cely the younger (d. 1493). Other core members of the Cely family (see figure 1) are John Cely, also a Merchant of the Staple who gathered wool for his brother Richard the elder, and Robert Cely (d. 1485), who had become full member of the Staple Fellowship by 1474-1475 (Hanham Celys..., 82). The bulk of the extant correspondence is written by William Cely (d. 1489), probably a family dependant who took over the job of factor at Calais when George returned to London; as such, he is not included in the family chart.

Most of the other correspondents are related to the wool trade, either as factors or as staplers. The former include Thomas Kesten -an associate of Richard the elder in charge of the Calais end of business- and the attorneys John Dalton and Thomas Granger. Merchants of the Staple include William Adam, John Dycons, William Dalton, Thomas Colton, John Eldurbeck, Ralph Lemyngton, William Maryon -a close friend and neighbour of the family- John Pasmer, John Sambach, Richard Ryisse, John Spencer and Harold Stawntoyn. Letters by the mercers Harry Bryan, Robert Eyrick and John Roose also appear. The collection also includes letters by the servants Robert Good and Joyce Parmenter and by the wool supplier William Mydwinter. Two letters by Robert Radclyff, the Major of the Stapler's Lieutenant at Calais, are also preserved. The gentry is represented by Sir John Weston, prior to the English branch of the order of St. John of Jerusalem (1476-1489) and the Cely's immediate patron, as well as by Sir Edmund Bedyngfeld, who was Knight of the 
Bath at the Coronation of Richard III in 1483, Sir Ralph Hastings (d. 1495) and Sir Roland Thornburght. There is one letter by an anonymous Vicar of Watford and some by unknown correspondents, like R. Coldale, Nicholas Knyveton, John Goldson, Thomas Miller, R. Shipden and the anonymous R.A. Finally, one letter addressed by Margery Cely to her husband George is also preserved.

Even if the headquarters of the Celys were situated at Mark Lane, near the Tower of London, the routines of the wool business involved a great deal of mobility in the form of journeys to the wool-producing regions of England, especially the Costwolds, thence to London, where wool was stored, and to Calais, where members of the Fellowship of the Staple were enforced by law to ship and sell their products at a fixed rate (Hanham Letters..., xviii-xix). In the late fifteenth century, Calais, which had been an outpost in France since 1346, was frequented by merchants of different nationalities: French, Dutch, Spanish, Lombards, German and English (Hanham Celys..., 222). Calais was clearly a multilingual town. Factors also travelled from Calais to different marts in the Low Countries -Antwerp, Bergen-op-Zoom and, especially, Bruges- where diverse economic transactions were made, involving other English staplers and merchant adventurers, but also Lombard or Flemish bankers and Spanish businessmen. The marts were also attractive for shopping, and some of the letters contain lists of products that merchants, their family and friends asked factors to get for them (Hanham Letters..., xix; Hanham Celys...,115-147). In this context, language contact must have been the norm. ${ }^{1}$

Despite this multilingual setting, there is evidence that people of various origins dwelt in different streets and frequented different inns. But there is also evidence that settlements were often arranged in public houses, although the extent to which bargaining involved the use of the foreign language by any of the parts is unclear. Obviously, a spoken command of French and/or Dutch would have been useful for merchants and factors and there are proofs that apprentices were often trained in languages (Stenroos 25). In the Paston Letters a young man is recommended as being "well spokyn jn Inglyshe, metly well in Frensche and very parfit in Flemyshe. He can wryght and reed" (Davis 600; see also: Hanham Celys..., 248). Similarly, the French-English phrase book published by William Caxton in c. 1480, Dialogues in French and English, contains model bilingual conversations "on toures and fayrs" / "villes et festes" or "the marchandyse of wulle" / "les marchandises des laires" (Bradley 1; see also: Hanham "Who made...?" 715; Häckner 144); despite its obvious interest for merchants, there is no evidence that the Celys were able to use it. ${ }^{2}$

${ }^{1}$ As such, one letter in Dutch and two French ones appear in the collection. The Dutch letter was addressed to George Cely by Jan Vanderheyde in October 1477 asking to be sent "iiij sacken myddel Cutsewout" ['four sarplers middle Costwold'] (Hanham Letters..., no. 14, 11. 6-7). Two letters in French are also included: a well-known letter sent by Clare to George Cely in May 1479 where she declares her love for him (no. 54) and one letter addressed by Waterin Tabardy to George Cely promising to send "vng home porteur [decheste] pour conduire l'omme as hotoirs" (no. 62, 11. 2-3).

2 These are clues that French in fifteenth-century England was still learnt in some circles, together with Latin, in parallel to literacy training (Schendl and Wright 19; see also: Ingham "Anglo- 
Martina Häcker has claimed that knowledge of French among the Celys could have been limited. She reaches this conclusion after the analysis of the lexicon used by the core correspondents and the absence of significant differences in the stock used by the members of the family who remained in London and those who were stationed at Calais. Moreover, she notices that the majority of non-English technical terms related to the wool trade are Flemish, which, from her point of view, discards that a suitable command of French accompanied negotiations in Flanders (and Calais): "English and Dutch must [...] have been close enough for English settlers to understand Dutch buyers and vice versa. For negotiations with French buyers English merchants would probably have used intermediaries" (144-145). In this sense, bargaining with "Hollandars" is described by Richard Cely the younger in a letter sent from Calais to George Cely in September 1478:

Syr, her be com iiij felyschyp of Hollandars - thay be the harddeste men that euer I spake with [...] Syr, I wos in hand wyth them for owr fellys, and set the Cottyswold at xiiij [noblys] xx d., or not, and contre at xiij noblys xl d., or not, and then tay wold refewy a scarttayn and I wald not, and wat thay wyll do I wotte not zeyt (Hanham Letters..., no. 34, 11. 14-21)

In the same letter, Richard describes his deals with French "marchantys of Roon" [Rouen]:

Syr, her ys marchantys of Roon, and thay wolde by good Cottyswold woll, and thay spake to me and desyryd to haue had iij sarplers, iij partys in hand of payment xxv s. iiij d. my li., and halfe zer daye of the therd penny, mony corant in Flandyrs. And I ansford them and thay wold geue me redy mony xxv s. iiij d., mony corant at Calles [...] thay schould haue iij or iiij. And watt thay wyll do I wot not zeyt (Hanham Letters..., no. 34, 11. 4-11)

No reference is made in these texts to the language used in the negotiations; however, the vividness of the description seems to imply that, in both contexts -English-Dutch and English-French- both parties were involved in conversation and understood each other, probably using their own language, since no interpreters, either in the French or the Dutch languages, are mentioned.

Norman...," 1-7; Ingham Transmission..., 27-38). Tim William Machan has studied the circulation of French grammars in the late fourteenth and fifteenth centuries and finds evidence that French was still "a language with prestige in certain repertoires" (367; see also: Bennett 332). He gives notice of fifty-two printed manuals for teaching French to English speakers in the fifteenth century; a figure that increases to one hundred and thirty nine in the sixteenth. Some of them, like Manières de langage (1396), the anonymous Liber Donati (early fifteenth-century) or William Caxton's Dialogues in French and English (c. 1480), included "model putative conversations for travellers and merchants working in France" or collections of legal and commercial texts in French, which leads Machan to compare them to "modern Berlitz book[s]" (368; see also: Rothwell 546). In addition to the cultural allure of French, this also points to a pragmatic interest on the part of French learners in late medieval England. 
Distinguishing between oral and written skills in French may be useful in this context, leading to the possibility that some of the Celys -particularly those at Calais-could have acquired some command of the former, but not of the latter. Evidence of this can perhaps be drawn from the well-known bilingual French-English notes scattered at the dorse of letter no. 49, originally sent to George Cely by John Dalton (15 April, 1479), but reused later by the recipient to scribble his own notes. These notes contain the following four lines of French text, probably corresponding to the lyrics of a drinking song:

Je boy Avous mademoy selle / Je vous plage movnsenyuevr // Poirsse ke vous l estes se belle / Je boy, etc.

Je sens lamor rensson estyn selle ke me persse par me le kowre /

Je boy a [...] Je voue plege movnsenywr / (Hanham Letters..., no. 49, 11. 12-15)

"I drink to you, mademoiselle / I pledge you, sir // Because you are so pretty / I drink, etc. I feel love in its spark which pierces me through the heart / I drink [...] I pledge you, sir /"

(Hanham Celys..., 50)

They are followed by a list of French words and phrases -which I have highlighted in italics- with their English translation, in the fashion of a French lesson:

de davns wyth in / de horsse wyth hov[te] Bosonye besy //

shavnte // syng / // vn shavnssoune / an song

lere / Rede vn shen an doge / shovtt hott

ffrett covld

Je le vous hay de kavnt je Raye / I have sayd yow whan

I go // Je swy hountesse / shamed Je swy Hountesse //

I am shamyd (Hanham Letters..., no. 49, 11. 16-22; my italics).

It is possible, Alison Hanham surmises (Celys..., 50), that George wrote these notes while he was in the company of a French-speaking lady, as suggested by the feminine ending in "Je swy Hovntesse"; this lady was probably Clare, who had written a French love letter to him (no. 54) and had probably become his mistress by the time the notes were scribbled. The lady may have been dictating the French lyrics to George and then, noticing that he was not writing properly, interrupted the transcription to teach him some useful French words and phrases, which her lover wrote down, together with the English translation. An interesting issue here is the defective command of written French on the part of George, whose spelling of French words is almost phonetic, as the mere comparison of the third line "Je sens lamor rensson estyn selle ke me persse par me le kowre" with the correct French version "Je sens l'amour en son étincelle qui me perce par mi le coeur" clearly shows. Other instances of this phonetic rendering of French are reflected in the omission of final mute $<\mathrm{t}>$ as in $d e$ (French dit) and $\langle s>$ in swy (French suis). Likewise, sometimes spaces are inserted before stressed syllables, separating articles and pronouns from nominal or verbal forms, as in horse (French de-hors) or "je Raye" (French j'irais). This suggests that George Cely is following here the English stress-based system of word division, with primary stress falling on the first root syllable (Häcker 142- 
143). Nevertheless, I believe that from the flagrant written French mistakes in this playful lesson, one cannot conclude that George Cely was wholly unfamiliar with oral French; obviously he could communicate with Clare "to their mutual satisfaction" and, as seen above, he had dealings with French-speaking customers. It is clear that he could not write French properly, but "in his business dealings [he] had probably little need to [do it] [...] and it seems unlikely that he was quite so ignorant of the spoken language" (Hanham Celys..., 50-51). To a certain extent, George and other members of the family staying at Calais may have been "naturalistic" or "folk bilinguals" who had learnt some rudiments of the second language (French) through first-hand contact with people speaking it, but had not received the formal instruction that "elite bilinguals" did (Skutnabb-Kangas 97). This is the context for my study of code-switching and borrowing in the Cely letters.

\section{PROBLEMS IN THE CONTINUUM FROM CODE-SWITCHING TO BORROWING}

Code-Switching and borrowing have been situated by a majority of scholars within a cline, especially from the diachronic perspective which assumes that switches, in the course of time, may become fully accepted borrowings:

Every loan presumably starts life as spontaneous code-switching and some of the switches then generalize themselves among speakers of the host language. The diachronic nature of this process is shown by the fact that transfers which occur at different historical stages of contact between the languages may go through quite different processes of integration and end up looking quite different in the receiving language (Gardner-Chloros "Contact...," 195; see also: Gardner-Chloros Code-Switching, 12; Thomason "Contact...," 694-696).

Scholars usually rely on the classical criteria of integration -at structural and community levels- and frequency to distinguish between established or integrated borrowings and code-switching (Poplack, Sankoff and Miller). The former usually show structural integration -morpho-phonological and semantic, reflected in the displacement of native synonyms- and, at the social level, relative acceptance by the community, which often leads to repeated use in the repertoire of more and more community members (frequency). The latter, however, tend to be limited in number; they are usually accepted in the speech of bilinguals, but may be rejected by many monolingual speakers (Appel and Muysken 182; Romaine 112-114; Gómez Capuz 150-153; Gimeno and Gimeno 119). Despite general reliability, these criteria have exceptions: not all loanwords are morpho-phonologically assimilated into the receiving language and not all code-switches are spontaneous or transient; some oneword switches may become recurrent in the community language even if they lack linguistic integration (Winford 182). Additional problems impinge on the application of these criteria to the analysis of historical materials, especially medieval ones. Arja Nurmi and Päivi Pahta have summarised them as follows: 
... [ $\mathrm{t}$ ]he most commonly used criteria, structural integration and frequency, are difficult to apply. As structural integration of a lexical item is continuous rather than discrete, in a historical perspective it is often impossible to determine the degree to which a given item has been assimilated into the host language at a given point. Defining the degree of phonological assimilation from written evidence is also problematic. The assessment is complicated by fluctuation in spelling, and the use of abbreviations and suspensions in medieval handwriting suppresses the distinction further [...] Frequency does not serve as a firm basis for classification either. Often there is not enough evidence to determine whether a word was frequent in the usage of an individual or widespread in the community at the time (425). ${ }^{3}$

Integration and frequency alone are not sufficient criteria to distinguish "one-word insertional switches" from "non-assimilated borrowings": "on the spot borrowings that are structurally integrated but have not necessarily reached a wide level of propagation within the speech community or within a corpus" (Matras 106; see also: Winford 172-173). Shana Poplack, David Sankoff and Christopher Miller proposed the term "nonce borrowings" for those one-word items, probably spontaneous in the speech of bilinguals, which have a very low frequency of occurrence in a given data corpus -sometimes they occur only once- but, however, are already morphosyntactically integrated in the receiving language. As such they contrast with "established loanwords" which, in addition to full linguistic integration, show widespread diffusion across the community (50; see also: Poplack and Sankoff 102-105; Poplack and Meechan 131-132; Thomason Language Contact, 133-136; Gardner-Chloros Code-Switching, 12). The existence of exceptions -see, among others, Treffers-Daller, Samar and Meechan, Stammers and Deucharhas led some authors to question the necessity of using separate labels for these two lexical outcomes of language contact. For instance, Barbara E. Bullock and Almeida Jacqueline Toribio avoid the term code-switching in this context and use "unassimilated borrowing" for all one-word lexical instances (5), while Michael Clyne prefers switches to embrace all individual lexical transferences and proposes "transmission" for complete crossings from one language onto another (75; see also: Myers-Scotton "Comparing..., 20-22").

One sensible solution is to look individually at each problematic instance before deciding on its status as a conscious code-switch, a "one-off occurrence" or

${ }^{3}$ Scribal conventions such as abbreviations and suspensions, among others, may also impinge on the clearcut distinction of codes in cases of medieval written languages in contact; the difficulty of attributing abbreviated words and morphemes to one language or another may be added to the extensive range of variability in texts from the period and the absence of contemporary descriptions which may help take definite decisions (Nurmi and Pahta 425). In this sense, GardnerChloros avoids referring to codes or matrices in studying historical contact phenonema: they are "produced by individuals who use their repertoire of languages according to circumstance; what belongs to one language and what belongs to another is not necessarily clear and identifying a single primary language in bilingual speech or writing may not be possible" ("Historical...", 24-25; see also: Gardner-Chloros Code-Switching, 10-13; Pahta 530-531; Pahta, Skaffari and Wright 7). 


\begin{tabular}{c} 
Bilinguality \\
bilingual speaker $\leftrightarrow$ monolingual speaker \\
Composition \\
elaborate utterance/phrase $\leftrightarrow$ single lexical item \\
Functionality \\
special conversational effect, stylistic choice $\leftrightarrow$ default expression \\
\hline Unique referent (specificity) \\
lexical $\leftrightarrow$ para-lexical \\
Operationality \\
core vocabulary $\leftrightarrow$ grammatical operations \\
Regularity \\
single occurrence $\leftrightarrow$ regular occurrence \\
Structural integration \\
not integrated $\leftrightarrow$ integrated \\
codeswitching $\leftrightarrow$ borrowing
\end{tabular}

Figure 2. Dimensions of the code-switching borrowing contimuum (Matras 111).

an integrated borrowing (Gardner-Chloros Code-Switching, 12). With this aim, scholars have proposed further criteria. Myers-Scotton (Duelling..., 175-202), in addition to linguistic integration and diffusion across the community, also handles dictionary and age of attestation to refine the loanword/code-switching divide -see also, among others, Schatz, Pfaff and Backus. In his seminal handbook Language Contact, Yuron Matras has proposed a complete set (110-114). Some of his criteria have been successfully applied by Herbert Schendl ("Code-Switching...," 39-59) to the analysis of texts from the history of English, particularly to tell switches into Latin from Latin borrowings in the Dictionary of Old English Corpus. ${ }^{4}$ In discussing these criteria (see figure 2), I will combine Matras's description with Schendl's reformulation for historical application. Both authors, however, see each criterion as a continuum in itself -within the broader code-switching cline defined previously.

${ }^{4}$ For the application of these and other criteria to the elicitation of borrowings and codeswitches in different texts and periods in the history of English see, among others, Schendl ("Linguistic aspects...," "Mixed-language..." and "Multilingualism..."), Nurmi and Pahta, Crespo and Moskowich, Gardner-Chloros ("Historical..."), as well as the different chapters in the volumes Code-Switching in Early English (Schendl and Wright, eds.) and Multilingual Practices in Language History (Pahta, Skaffari and Wright eds.). 
1. The "bilinguality continuum." Matras understands "bilinguality" as a lax concept which can be extended from the ability to use two or more languages, in different degrees, to cases when there is just a rudimentary knowledge of one of the languages involved in the contact situation. In this continuum the key issue to distinguish switches from borrowings is the ability of the individual to maintain the separation between subsets of his or her linguistic repertoire using them in separate contexts, so that "monolingual speakers are not able to activate any word form from another code and only incorporate borrowings through the diachronic process of propagation through the speech community" (Matras 211). Obviously, this is an extreme situation, especially in the late medieval context and in the multilingual background where most of the Cely letters were produced; in this case some degree of mixing, -i.e. "of drawing elements of the full repertoire regardless of subset affiliation"- would have been expected (128).

2. The "functionality continuum" situates code-switches as "conscious and discourse-strategic" elements more likely to fulfill special effects -textual, stylistic, conversational, etc. - than borrowings. As such, code-switches are often "triggered in a non-random way by situational or contextual factors [and they] constitute an alternative to a default formulation of the same propositional content" (Matras 112). At the other end of the continuum, borrowings are often "the only expression in the language representing the particular concept" (112).

3. The "specificity continuum" assumes that some one-word switches usually "entail a referencing procedure [...] beyond the generic labelling of concepts or objects and resemble the assignment of word-forms as individualised identity badges," in this way approaching the borrowing end of the continuum (Matras 112). This means that loans are more likely to fill in a lexical gap in the receiving language or may involve the displacement of synonyms, while code-switches tend to add themselves as a further option to the native equivalent (Gardner-Chloros Code-Switching, 32; Gardner-Chloros "Contact...," 196). This may be reflected in technical and institutional vocabulary as well as in local affectionate terms of address.

4. The "structural integration continuum" understands switches as morphologically non-integrated elements, despite being usually syntactically integrated. On the contrary, borrowings are both morphologically and syntactically integrated. As regards non-assimilated borrowings, the degree of phonological integration is a key issue, since, by definition, this is gradual and variable, as most examples from the Cely letters will show.

5. Structural integration can be related to the "compositional continuum" which contemplates "the uniqueness and context dependency of the structure that is derived from the other language," with context-dependent insertions approaching switches and, vice versa, borrowings being freely established elements (Matras 112).

6. The "regularity of occurrence continuum" considers that switches usually have an overall low frequency of occurrence and a restricted textual distribution, 
while borrowings are "deemed appropriate in whichever language context that is being activated" (Matras 113).

7. Finally, code-switches and borrowings have to be situated in an "operationality continuum" where the latter tend to be produced "non-consciuosly in order to reduce the processing effort associated with the selection/inhibition mechanism" while the former usually require maintaining "consistent control over the selection mechanism around automated, non-referential operational elements such as discourse markers, indefinites, etc." (Matras 113). This may be connected with the replicability of borrowed items by monolingual speakers and in successive monolingual contexts (147).

The application of these criteria has allowed Matras to differentiate prototypical instances of one-word switches from assimilated borrowings in the following terms:

The prototypical, least controversial kind of borrowing thus involves the regular occurrence of a structurally integrated, single lexical item that is used as a default expression, often a designation for a unique referent or grammatical marker, in a monolingual context. The least controversial code-switch is an alternational switch at the utterance level, produced by a bilingual consciously and by choice, as a single occurrence, for special stylistic effects (Matras 113-114).

The organisation of these criteria into a cline also allows to distinguish different sections in the continuum, so that refined gradings can be established to accommodate other outcomes such as non-assimilated or nonce borrowings, among others.

\section{ONE-WORD LEXICAL SWITCHES AND NON-ASSIMILATED (NONCE) BORROWINGS IN THE CELY LETTERS}

\subsection{Methodology}

In this section the above criteria will be applied to analyse some vocabulary items from the Cely letters which are neither clear one-word lexical switches nor well-established borrowings but can easily be located in different spots of the cline between them. Most of the items selected are not included in the canonical historical dictionaries: the Oxford English Dictionary Online (Simpson, Profitt et al.; henceforth $O E D$ ) and the Middle English Dictionary (Lewis et al.; henceforth MED). However, some words included in these sources have also been analysed, either because the text from the Cely letters exemplifies an earlier attestation, or because they reflect a minor spelling -and possibly phonological- variant of a contemporary lemma. All the items analysed have been selected after the careful perusal of the letters -the methodology of corpus linguistics being difficult to implement- which also means that the lists of items is far from exhaustive. As a matter of fact, the complete analysis of the vocabulary in the Cely letters is beyond the scope of this paper, which simply 
aims at testing the reliability of Matras's criteria and their usefulness for the study of the historical lexicon.

The lexical items have been plotted against most of the categories discussed above, except "operationality," which, as a psycholinguistic concept, would probably need a personal contact with informants to be discerned. The fact that I am dealing only with lexical, detachable elements means that they are all context-free and, as a result, they are all "compositionally integrated," which makes this category irrelevant for the analysis. Etymological, contextual and linguistic information has been drawn for each item and each criterion has been scored in a range of 1 , 0.5 or 0 -or sometimes 1 and 0 - thus establishing a cline in which 1 is nearer the borrowing end of the spectrum and 0 nearer the switching one. This procedure also implies that some of the categories have been renamed as, for instance, "nonbilinguality" or "non-functionality" in order to agree with the positive significance of the scoring process.

1. Non-bilinguality. Scores in this category are assigned according to the background of the informant, in the belief that those who had stayed or remained at Calais would have been immersed in a multilingual context $(0)$ while those who remained in London were not (1), unless there is evidence that they had some training in French and/or Dutch. Writers, like Richard Cely the younger, who spent some time at Calais but returned to London and spent most of his life there are assigned 0.5.

2. Non-functionality. In this case 0 applies to lexical items which, in addition to their referential function, fulfill some discoursive or textual ones, and 1 to purely referential elements.

3. Specificity. Scores in this category are assigned by looking at the semantic extent of the lexical item. Some of them clearly fill a lexical gap in the receiving language which means that they are nearer the borrowing end of the continuum and score 1; on the contrary, if they are not filling a gap they score 0 . The existence of residual synonyms or variants in the receiving language scores 0.5 .

4. Structural integration. All the items selected for analysis are morphologically integrated, so one key issue here is phonological integration, which is marked with $1,0.5$ or 0 depending on the degree of separation from the source language.

5. Regularity of occurrence. Scores are given considering whether the lexical item appears in other texts or not. Items which are used only once in the Cely letters and/or are limited to letters by the same author score 0 , while those appearing in several letters by different authors score 0.5; finally, words featuring in other texts from the period would show a high degree of community integration and score 1 . In the case of lemmas included in the reference sources, some degree of integration (at least 0.5) is assumed. 


\subsection{RESULTS AND DISCUSSION}

These criteria have been applied to fourteen different items with the results displayed in table 1, which reflects their position nearer or further from the switching end of the cline:

\begin{tabular}{|c|c|c|c|c|c|c|}
\hline & $\begin{array}{c}\text { NoN- } \\
\text { BILINGUALITY }\end{array}$ & $\begin{array}{l}\text { Non- } \\
\text { FUNCTIONALITY }\end{array}$ & Specificity & INTEGRATION & Regularity & Total \\
\hline ESSYNGLAR & 0 & 0.5 & $0 / 0.5$ & $0 / 0.5$ & 0 & $0.5 / 1.5$ \\
\hline$A M B A W G H T(E R)$ & 0 & 1 & 0 & 0.5 & 0 & 1.5 \\
\hline MALEFFETT & 0 & 1 & 0 & 0.5 & 0 & 1.5 \\
\hline ABESAUNCE & 0 & 1 & 0.5 & 0.5 & 0 & 2 \\
\hline VENT, WENTE & 0.5 & 1 & 0 & 0 & 0.5 & 2 \\
\hline GRUFF & 0 & 1 & 1 & 0.5 & $0 / 0.5$ & $2.5 / 3$ \\
\hline PATTYSCH[YD] & 0.5 & 1 & 0.5 & 1 & 0 & 3 \\
\hline FFORHOWSE & 0 & 1 & 1 & 1 & $0 / 0.5$ & $3 / 3.5$ \\
\hline YNSCHYPPYNG & 0 & 1 & 1 & 1 & $0 / 0.5$ & $3 / 3.5$ \\
\hline BOWHAY & 0.5 & 1 & 1 & 1 & 0 & 3.5 \\
\hline CLOT & 1 & 1 & 1 & 0 & $0.5 / 1$ & $3.5 / 4$ \\
\hline SYNKSEN & 1 & 1 & 1 & 0.5 & 0.5 & 4 \\
\hline HOWYSER & 1 & 1 & 1 & 1 & $0.5 / 1$ & $4.5 / 5$ \\
\hline INUIATORY & 0.5 & 1 & 1 & 1 & $0.5 / 1$ & $4 / 4.5$ \\
\hline
\end{tabular}

ESSYNGLAR, with a score of $0.5 / 1.5$, is the item nearest the switching end of the cline. It is an adjective used by George Cely in the opening salutation of a letter sent from Calais to Sir Thomas Weston (non-bilinguality = 0): "Ryhht whorshypffull syr and myn essynglar good Lord" (Hanham Letters..., no. 178, l. 1). The OED does not record this form, which is probably a variant of singler ( $<$ Old French sengler, sangler) recorded by the $M E D$ with the meaning "excellent" in a similar letter context in 1447 (s.v., adj ${ }^{1 \mathrm{~b}}$ ). Its presence in the formulaic opening of the letter confers upon it a discoursive, ritualistic function added to its referential meaning (non-functionality $=0.5$ ). As regards specificity, the presence of alternative synonyms in English, such as excellent (since c. $1400, O E D$ s.v.) may also imply a reduced score (0.5). There is a slight orthographical deviation from the French source -the ending <-er> replacing the French <-ar>-, although this may be due to a reinterpretation of the word in connection with Latin singularis, which would score 0 in integration. No other attestations of this form have been found (regularity $=0$ ).

AMBAWGHT(ERS) scores 1.5 and is also near the switching end. It is used by William Cely to describe an "embassy" or the "ambassadors" participating in it: 
"last passyd all the ambawght..." (no. 242, 11. 1-2) (non-bilinguality = 0). As such, this is probably modelled on Dutch ambacht(er) and contrasts with the systematic use in the corrrespondence of the French borrowing AMBASSADOR, with the variants ambassettor, imbassettor, inbassador, inbassetorys, which the OED traces back to c. 1374 (s.v., $n$.) and is also common in other letters by William Cely himself. The word has no specific textual or discourse function (non-functionality $=1$ ), and, by the time it was used, there were already synonyms well-integrated in English (specificity $=0$ ). This item shows only a slight adaptation into English, with the mere addition of the final sequence $<$ wght $>$ instead of the original $<$ cht $>$ (structural integration $=0.5$ ). There are no other attestations (regularity $=0$ ).

A similar case is MALEFFETT (1.5) which appears twice in a letter sent from Calais by William Cely (non-bilinguality $=0$ ): "ffor any malefette don be any oder Englysche man" (no. 213, 1. 39) and "ffor noo malefett doon by any Flemyng" (l. $39)$. As such, this item is not included either in the $O E D$ or in the $M E D$, although malefit appears in the former with the meaning "[a] misfortune, a disadvantage" first attested in 1755 (s.v., $n$.). The meaning of malefett, probably based on French malfait, is clearly "offence" (Hanham Letters..., 326). It has a purely referential function (non-functionality $=1$ ). As regards specificity, it does not fill any lexical gap in the receiving language (0) and its structural integration into English is minimal, with a mere change from French <ai $>$ to English $<\mathrm{e}>(0.5)$. No other attestation of this item has been found (regularity $=0$ ) which means that it is near the switching end of the cline.

ABESAUNCE scores 2 and approaches the central part of the cline. It is used by William Cely in a letter sent from Calais and therefore scores 0 in nonbilinguality: "[a]nd the cheyffe rewlers of Gaunte be com to Brugys [...] to be vnder the abesaunce of the Kynge of Fraunce" (no. 241, 11. 18-20). This word probably results from a confusion of the Anglo-Norman borrowing obeisance - "the action or fact of obeying," attested, according to the OED, since 1382 (s.v., n) - with the later loan abaisance (<Central French abessance): "the act of expressing deference or respect, usually a bending forward of the body"; this is first attested in Ordinances of Chivalry from 1486, one year before William wrote this letter (OED s.v., $n$; see also: Hanham Letters..., 301). Abesaunce does not perform any specific discourse or textual function in the letter (non-functionality $=1$ ); it does not fill a lexical gap either, although the confusion with an already existing loan may score 0.5 in specificity. As regards phonological adaptation, the partial reorganisation on the basis of obeisance-introduction of $<\mathrm{e}>$ and insertion of $<\mathrm{u}>$ in the -ance endingpoints to some degree of integration into English (0.5). William Cely is the only user of this form, which means that it scores 0 in regularity.

VENT, WENTE also scores 2. It appears in letters by William Cely -"here hathe ben a grett vent of end wull" (no. 220, 1. 35)- and Richard Cely the younger (no. 147, 1. 19): "I thynke heffe he hawthe any wente at Calles" (no. 147) (nonbilinguality $=0.5)$. Both are based on French vente, meaning "sale," whose first 
attestation as a noun in the $O E D$ is from 1548 (s.v., n.). If so, the Celys appear to be among the earliest users of this referential item (non-functionality $=1$ ). It lacks, however, complete specificity in so far as it does not fill a lexical gap in the receiving language and synonyms exist (0), like sale (< Old Norse sala) (OED s.v., $n_{._{2}}$ ) and purchase (< Anglo-Norman purchas) attested since the early fourteenth-century (OED s.v., n.). It is not phonologically integrated into English (0), but probably enjoyed some regularity of use, at least among the merchant community at Calais and the Low Countries (0.5).

With a score of 2.5/3, GRUFF is in the middle of the cline. It is used once by William Cely to describe second-class or coarse wool: "hytt ys a very gruff wull" (no. 234, l. 53) (non-bilinguality = 0). The connection to Middle Dutch grof is confirmed by the $O E D$, which mentions a first attestation from 1533. (s.v., adj. ${ }^{1 a}$ ). This example from the Cely letters is obviously an earlier instance of a technical term (specificity $=1$ ) which has no additional discoursive or textual function (nonfunctionality $=1$ ). However, its structural integration is low, based on a change of the root vowel $\langle 0\rangle$ for $\langle\mathrm{u}\rangle$. The absence of regularity may again be due to the lack of additional written evidence from merchants and factors in Calais, among whom, as a technical term, this would probably have been widespread (regularity $=0 / 0.5$ ).

PATTYSCH[YD] scores 3 and is also in the middle of the cline. The phrase " $[\mathrm{w}]$ hord is heyr that [...] Gawnt and Bergys ys pattyschyd to the Frensche kyng" (no. $169,11.22-24$ ) is used by Richard Cely the younger to announce the treatise signed between Gaunt-Bruges and the French, probably in 1482 (Hanham Letters..., 281). It scores 0.5 in non-bilinguality. The word is neither listed in the $O E D$ nor in the MED. According to Hanham this may be based on Old French * patiser or French pactiser, "to come to terms with" (Letters..., 330). As such, it has no additional discoursive function (non-functionality $=1$ ), and it is highly integrated in orthographical and possibly phonological terms (structural integration $=1$ ). Nevertheless, it is not a technolect filling a gap in the language, since other synonyms for it, such as accord and agree, are attested respectively in the early fourteenth $\left(O E D\right.$, s.v., $\left.v .{ }^{\text {Ila }}\right)$ and fifteenth centuries $\left(O E D\right.$, s.v., $\left.v .{ }^{\mathrm{II} 3 a}\right)$ (specificity $\left.=0.5\right)$. No other instance of this term has been found (regularity $=0$ ).

FFORHOWSE, with a score of $3 / 3.5$, is used by George Cely in a letter sent from Calais (non-bilinguality $=0$ ) to express the action of "moving wool from one store to another": "I prayow lat Kay fforhowsse the xx sarplers off my ffaders owt of John Prowdys wollhowsse vnto the wollhowsse besyde my stabull" (no. 105, 11. 25-26). As such, it is not included in either the $O E D$ or in the MED. A likely connection with Dutch verhuizen (removal) is proposed by Hanham (Letters..., 317). If so, this would be nearer the borrowing end of the continuum, scoring one point in both non-functionality and specificity, in so far as the word fills a lexical gap in the receiving language and has no additional discoursive of textual functions. It is highly adapted to English spelling (and possibly phonology) and scores one point in structural integration. The absence of further attestations is the only aspect hindering 
its classification as an assimilated borrowing, although it simply may be due to lack of evidence (regularity $=0 / 0.5$ )

$Y_{N S C H Y P P Y N G}$ also scores 3/3.5. It is used by William Cely with the meaning of "[t]o put into a ship [...]; to embark": "they schuld cause men to londd agayne syche gooddys as they were ynschyppyng wythal" (no. 212, 11. 47-48) (non-bilinguality = 0 ). The $O E D$ includes the word, but gives the date 1615 for the earliest attestation, etymologically relating it to Middle Dutch inscepen (s.v., v.). The use in the Cely letters certainly antedates this example. As an exclusively referential (non-functionality $=1$ ) and structurally well-integrated (1) lexical item, it appears to be situated at the borrowing end of the continuum, showing a high degree of specificity (1); however, it is not attested as a regular Middle English word, although it is likely that other shipmen at Calais were familiar with the Dutch term and its incipient adaptation into English (regularity $=0 / 0.5$ )

BOWHAY scores 3/3.5 in the cline. Richard Cely the younger uses this form in a letter sent from London (non-bilinguality $=0.5$ ): "as for your pesse of gowlde whe cannot fynd hyt zeyt, nethur heyr no whord of my bowhay" (no. 126, 11. 1-2). It has been interpreted as a variant of BOY, referring to "a male servant, slave, assistant, junior employee" (OED s.v., $\left.n .{ }^{12}\right)$; however, the $O E D$ does not include bowhay among the fifteenth-century variants, although boay and boaye appear. The ambiguity of the context, together with the fact that the two Cely brothers normally used boy(e) may question this interpretation. Alison Hanham relates it to Flemish boe or Middle Dutch boeier: "a medium-sized vessel [...] popular in the sixteenth century for trading between Britain and the Low Countries" (Letters..., 274). She also contemplates a relationship to French boie/buie, meaning "a bowl, a vessel for liquids or a tub" -a kind of barrel in which goods were packed (274). In either case, it is a technical term (specificity $=1$ ) with no additional discourse or textual function (non-functionality $=1$ ). It is highly adapted to English spelling (structural integration =1), despite nonexisting evidence of further attestations (regularity $=0$ ).

CLOT scores 3.5./4 and approaches the borrowing end of the continuum. It is used by Richard Cely the elder: "I sopose it wyll coste a vj s. or vij s. clotys, lynys spynys and all" (no. 56, 11. 17-18). It is included in the $O E D$ as a fifteenthcentury variant of cleat-"a wedge"- with possible influence from Middle Dutch clot, as shown in The Promptorium Parvulorum (c. 1449): "clyte or clote, a vegge" (s.v., n.; see also: Hanham Letters..., 263). The use by a non-bilingual speaker with no direct contact with the multilingual reality of Calais means a score of 1 in nonbilinguality. It is a technical term with an exclusively referential function (specificity $=1$; non-functionality $=1$ ). However, the retention of the Dutch spelling points to the absence of structural integration (0), although the similarity between both languages may account for this. Finally, as regards regularity of use, its inclusion as a variant in the $O E D$ may point to some circulation outside this letter, at least among members of the merchant classes (regularity $=0.5 / 1$ ). 
SYNKSEN and its variants - Syncyon, Synxon, Syn(s)chon, Synsson, Syngsyon, Sencyon, Senschon and Senchan- refer to the mart celebrated in Antwerp during the Whitsun festivity. It scores 4 and appears at the borrowing end of the cline. As such, it is etymologically connected with Middle Dutch sinsken, although it does not appear in the $O E D$ or in the $M E D$. The number of variants, together with its use by several correspondents (William Cely, George Cely, Richard Cely the younger), some of them with no direct contact with the continental side of business -Richard Cely the elder, John Dalton, John Cely-may imply that it is a highly technical term (specificity $=1$ ) with a high score in non-bilinguality (1). It is also regularly used in the Cely letters, although no attestations elsewhere have been found (regularity = $0.5)$. It is obviously a pure referential term, with no additional discoursive or textual functions (non-functionality $=1$ ). The different variants show distinct degrees of phonological and spelling adaptation, although its "foreing" origin can still be recognised (structural integration $=0.5$ ).

HOWYSER shows the highest score in the borrowing end of the cline, 4.5/5. It is used in the heading to a list of expenses in George Cely's hand: "Logged at the howyser in Barow" (no. 151, 1. 49). The mercer Robert Eyrick mentions the same place in the endorsement of letter no. 154, sent from London to George Cely at Bergen-op-Zoom "beyng in the howyser at Barow" (1. 22). As such, it scores 1 in non-bilinguality. The term is not included in either the $O E D$ or the $M E D$ and, according to Hanham, it may be related to Middle Dutch huushere: "the concierge who, among other functions, took care of money and valuables for the merchants of his nation" (Letters..., 279). In the second example, the meaning may have shifted to "the house under [the howyser's] care," probably "set apart for the use of the English merchants at Bergen-op-Zoom" (279). This means that the word may have been common among the English community in Calais and the Low Countries and by extension among merchants in London. It scores one point in non-functionality and, as a semi-institutional name, it clearly fills a gap in the receiving language (specificity $=1$ ). It is also highly integrated into English spelling (structural integration =1). As regards regularity, the use by two correspondents in the collection means at least a score of 0.5 and, despite lack of evidence, does not exclude that other merchants could have used it (regularity $=0.5 / 1$ )

Finally, INUIATORY also shows the highest score, 4.5/5. It is described by Hanham as a "corruption of inventory" (Letters..., 322) and as such it is used by Richard Cely the younger: "I fynd the inuiatory of syche godys [...] on that syd of the see" (no. 165, 1l. 6-7) (non-bilinguality = 0.5). This attestation (from 1482) is earlier than the example included in the $O E D$ with the meaning "[a] list, catalogue; a detailed account," from 1589 (s.v., $n{ }^{2 a}$ ), and antedates in one year its use in the English-Latin wordbook Catholicum Anglicum (c. 1483) with the meaning: "a [...] list of articles [...] found to have been in the possession of a person at his decease or conviction" (s.v. n. ${ }^{1}$ ). The item is clearly used with a referential function (nonfunctionality $=1$ ) and fills a technical gap in the language (specificity $=1$ ). However, its inclusion in the 1483 glossary together with its Latin cognate -"Inuitory, 
inventarium"- may mean that it was not widely understood outside certain circles, which sanctions its technicality; comparison with Latin also evinces a degree of structural integration (1) and points to the regularity of its use (0.5/1).

\section{CONCLUSION}

The categorisation of other items in the Cely letters -and in many other late medieval English sources- is ambiguous and it is difficult to classify them in the continuum from code-switching to borrowing as either "one-word lexical switches" or as "non-assimilated (nonce) borrowings." There are, for instance, other words of French and Dutch origin whose first attestation in the $O E D$ is a quotation from the Cely letters: pawyn (Hanham Letters..., no. 71, 1. 7) - "[a] thing [...] given into another's keeping as security for a debt" $\left(O E D\right.$ s.v., $\left.n^{3}\right)$ - prest (no. 15, l. 14) - "to lend money; to advance a loan" (OED s.v., v.) - rasure (no. 142, 1. 30), as a variant of razer: "a level measure, chiefly used for grain" (OED s.v., $\left.n^{2}\right)$. Other French and Dutch terms are used as technical terminology to indicate different units of measure: awne (< French aune) (no. 136, 1. 40) - "a measure of length used chiefly for textiles [...] typically in the range of 55-195 centimetres," whose first attestation in the OED is also from the Cely letters (1481) (s.v., n.) - or blotte (< Middle Dutch bloot/blote) (no. 165, 1. 16), not attested as such in the $O E D$ and referring to "packs of wool weighing less than $364 \mathrm{lbs"} \mathrm{(Hanham} \mathrm{Letters...,} \mathrm{280).}$

\begin{tabular}{|c|c|c|}
\hline \multicolumn{3}{|c|}{$\begin{array}{l}\text { TABLE 2. ITEMS FROM THE CELY LETTERS IN THE CONTINUUM } \\
\text { FROM CODE-SWITCHING TO BORROWING }\end{array}$} \\
\hline \multirow[t]{10}{*}{ Code-switching } & 0 & \\
\hline & & ESSYNGLAR \\
\hline & 1 & \\
\hline & & AMBAWGHT(ER), MALEFFETT \\
\hline & 2 & ABESAUNCE, VENT/WENTE \\
\hline & & GRUFF \\
\hline & 3 & PATTYSCH[YD] \\
\hline & & RHOWSE, YNSCHYPPYNG, BOWHAY \\
\hline & 4 & CLOT, SYNKSEN \\
\hline & & HOWYSER, INUIATORY \\
\hline Borrowing & 5 & \\
\hline
\end{tabular}

My analysis has not intended to cover all lexical items in the corpus and has been limited to fourteen ambiguous ones. I think that it confirms, on the one hand, the soundness of Matras's criteria, not only for the distinction between oneword lexical switches and integrated borrowings, but also for discriminating other outcomes of language contact situated in-between them, particularly the so-called non-assimilated or nonce borrowings. The quantitative assesment of each of the 
categories proposed by Matras in connection to etymological, linguistic and other contextual information discriminates between those items which are neither proper switches nor integrated borrowings, by situating them nearer the code-switching or the borrowing ends of the continuum (see table 2). Items whose total score is less than two, such as abesaunce, ambawght, essynglar, malefett or vent/wente, could probably still be labelled as switches. Those items totalling a score of 3.5/4 to 4.5/5, including clot, howyser, inuiatory and synksen, would admit a definition as nearly integrated borrowings, notwithstanding their future relationship to the English lexicon. Items with scores between 2.5 and 3.5 -bowhay, fforhowse, gruff, pattysch (yd) or ynschypyng - could still be non-assimilated borrowings which, despite their origin in the necessity to name specific or technical referents, did not finally find their way into the English wordstock, possibly because their referential sphere was highly connected to aspects of business in Calais and the Low Countries. In any event, it seems that the criteria of specificity, integration and regularity are still basic in deciding on one or another categorisation. Eventually, I think these results leave the door open to the necessity of maintaining a distinctive terminology for the intermediate parts in the cline from code-switches to borrowings.

Reviews sent to author: 20 January 2020

Revised paper accepted for publication: 30 January 2020 


\section{WORKS CITED}

Appel, René \& Pieter Muysken. Language Contact and Bilingualism. London: Edward Arnold, 1987.

Auer, Peter. "From Codeswitching Via Language Mixing to Fused Lects: Toward a Dynamic Typology of Bilingual Speech.” International Journal of Bilingualism. 3.4 (1999): 309-332.

Backus, Ad. "A Usage-based Approach to Code-Switching. The Need for Reconciling Structure and fFunction." Code-Switching. Between Structural and Sociolinguistic Perspectives. Ed. Gerald Stell \& Kofi Yakpo. Berlin \& Boston, MA: Walter de Gruyter, 2015. 19-37.

Bennett, Michael. "France in England: Anglo-French Culture in the Reign of Edward III.” Language and Culture in Medieval Britain. The French of England c. 1100-c- 1500. Ed. Jocelyn Wogan-Browne, Carolyn Collette, Maryanne Kowaleski, Linne Mooney, Ad Putter \& David Trotter. Woodbridge: Boydell and Brewer, 2009. 320-333.

Bradley, Henry, eds. Dialogues in French and English by William Caxton, adapted from a fourteenth-century book of dialogues in French and Flemish. London: Kegan Paul, Trench, Trübner, 1900.

Bullock, Barbara E. \& Almeida Jacqueline Toribio. "Themes in the Study of Code-Switching." The Cambridge Handbook of Linguistic Code-Switching. Ed. Barbara E. Bullock \& Almeida Jacqueline Toribio. Cambridge: Cambridge UP, 2009. 1-17.

Clyne, Michael. Dynamics of Language Contact. Cambridge: Cambridge UP, 2003.

Crespo, Begońa \& Isabel Moskowich. "Latin Forms in Vernacular Scientific Writing: CodeSwitching or Borrowing?” Selected Proceedings of the 2005 Symposium on New Approaches in English Historical Lexis (HEL-LEX). Ed. R.W. McConchie, Olga Timofeeva, Heli Tissari \& Tanja Säily. Somerville, MA: Cascadilla Proceedings Project, 2006. 51-59.

Davis, Norman O. ed. Paston Letters and Papers of the Fifteenth Century (2 volumes). Oxford: Clarendon, 1971.

Gardner-Chloros, Penelope. Code-switching. Cambridge: Cambridge UP, 2009.

Gardner-Chloros, Penelope. "Contact and Code-Switching." The Handbook of Language Contact. Ed. Raymond Hickey. Oxford \& Malden, MA: Wiley-Blackwell, 2010. 188-206.

Gardner-Chloros, Penelope. "Historical and Modern Studies of Code-Switching: A Tale of Mutual Enrichment.” Multilingual Practices in Language History. Ed. Päivi Pahta, Janne Skaffari \& Laura Wright. Berlin \& Boston, MA: De Gruyter Mouton, 2017. 19-36.

Gimeno Menéndez, Francisco \& M.a Victoria Gimeno Menéndez. El Desplazamiento Lingüístico del Español por el Inglés. Madrid: Cátedra, 2003.

Gómez Capuz, Juan. El Préstamo Lingüístico: Conceptos, Problemas y Métodos. Valencia: Universitat de Valéncia, 1998.

Häcker, Marina. "French-English Linguistic and Cultural Contact in Medieval England: The Evidence of Letters.” AAA. Arbeiten aus Anglistik und Amerikanistik 36.2 (2011): 133-160.

Hanham, Alison, ed. The Cely Letters, 1472-1488. London \& New York, NY: Oxford UP, 1975.

Hanham, Alison, ed. The Celys and their World. An English Merchant Family of the Fifteenth Century. Cambridge: Cambridge UP, 1985.

Hanham, Alison. “Who Made William Caxton's Phrase-book?” The Review of English Studies 56. 227 (2005): 712-729. 
Ingham, Richard. "Anglo-Norman. New Themes, New Contexts." The Anglo-Norman Language and its Contexts. Ed. Richard Ingham. Woodbridge: York Medieval Press, 2010. 1-7.

Ingham, Richard. The Transmission of Anglo-Norman. Language History and Language Acquisition. Amsterdam \& Philadelphia, PA: John Benjamins, 2012.

Lewis, Robert E. et al., eds. Middle English Dictionary. Ann Arbor, MI: U of Michigan P, 19522001. Online edition in Middle English Comnpedium. Ed. Frances McSparran \& Paul Scaffner. Ann Arbor, MI: University of Michigan Digital Library Production Service. Web 22 Jan $2020<$ http://quod.lib.umich.edu/m/med> [MED].

Machan, Tim William. "French, English and the Late Medieval Linguistic Repertoire." Language and Culture in Medieval Britain. The French of England c. 1100-c- 1500. Ed. Jocelyn Wogan-Browne, Carolyn Collette, Maryanne Kowaleski, Linne Mooney, Ad Putter \& David Trotter. Woodbridge: Boydell and Brewer, 2009. 363-372.

Matras, Yaron. Language Contact. Cambridge: Cambridge UP, 2009.

Mrers-Scotton, Carol. "Comparing codeswitching and Borrowing.” Journal of Multilingual \& Multicultural Development 13. 1-2 (1992): 19-39.

Myers-Scotton, Carol. Duelling Languages: Grammatical Structure in Codeswitching. Oxford: Clarendon Press, 1993.

Nurmi, Arja \& Päivi Pahta. "Social Stratification and Patterns of Code-Switching in Early English Letters.” Multilingua 23 (2004): 417-456.

Pfaff, Carol W. "Contacts and Conflicts: Perspectives from Code-Switching Research.” Language Choices: Conditions, Constraints and Consequences. Ed. Martin Pütz. Amsterdam \& Philadelphia, PA: John Benjamins, 2012. 341-360.

Pahta, Päivi. "Code-Switching in English of the Middle Ages." The Oxford Handbook of the History of English. Ed. Terttu Nevalainen \& Elizabeth Closs Traugott. Oxford. Oxford UP, 2012. 528-537.

Pahta, Päivi, Janne Skaffari \& Laura Wright. "From Historical Code-Switching to Multilingual Practices in the Past." Multilingual Practices in Language History. Ed. Päivi Pahta, Janne Skaffari \& Laura Wright. Berlin \& Boston, MA: De Gruyter Mouton, 2017. 3-16.

Pahta, Päivi, Janne Skaffari \& Laura Wright, eds. Multilingual Practices in Language History. Berlin \& Boston, MA: De Gruyter Mouton, 2017.

Poplack, Shana \& David Sankoff. “Borrowing: The Synchrony of Integration.” Linguistics 22.1 (1984): 99-135.

Poplack, Shana, David Sankoff and Christopher Miller. "The Social Correlates and Linguistic Processes of Lexical Borrowing and Assimilation.” Linguistics 26.1 (1988): 47-104.

Poplack, Shana \& Marjory Meechan. “How Languages Fit together in Code-Mixing.” International Journal of Bilingualism 2.2 (1998): 127-138.

Romaine, Suzanne. Bilingualism. (2nd ed.). Oxford \& Cambridge, MA: Blackwell, 1995 (1989).

Rothwell, William. "English and French in England after 1362.” English Studies 82.6 (2001): 539-559.

Samar, Reza Ghaffar \& Marjory Meechan. "The Null Theory of Code-Switching Versus the Nonce Borrowing Hypothesis: Testing the Fit in Persian-English Bilingual Discourse." International Journal of Bilingualism 2.2 (1998): 203-219. 
Schatz, H.F. "Code-Switching or Borrowing? English Elements in the Dutch of Dutch-American Immigrants.” ITL. International Journal of Applied Linguistics 83. 1 (1989): 125-162.

Simpson, John A., Michael Proffitt et al. eds. Oxford English Dictionary Online. Oxford: Oxford UP, 2000-2020. Web 22 Jan 2020 <http://www.oed.com> [OED].

Schend, Herbert. "Linguistic Aspects of Language Mixing in Medieval Texts.” Multilingualism in Later Medieval England. Ed. David Trotter. Woodbridge: Boydell and Brewer, 2000. 77-92.

Schendl, Herbert. "Mixed-language Texts as Data and Evidence in English Historical Linguistics." Studies in the History of the English Language. A Millennial Perspective. Ed. Donka Minkova \& Robert Stockwell. Berlin \& New York, NY: Mouton de Gruyter, 2002. 51-78.

Schende, Herbert. "Multilingualism, Code-Switching, and Language Contact in Historical Sociolinguistics." The Handbook of Historical Sociolinguistics. Ed. Juan M. HernándezCampoy \& J. Camilo Conde-Silvestre. Oxford \& Malden, MA: Wiley-Blackwell, 2012. 520-530.

Schende, Herbert. "Code-Switching in Anglo-Saxon England: A Corpus-based Approach." Multilingual Practices in Language History. Ed. Päivi Pahta, Janne Skaffari \& Laura Wright. Berlin \& Boston, MA: De Gruyter Mouton, 2017. 39-59.

Schende, Herbert \& Laura Wright. "Code-Switching in Early English: Historical Background and Methodological and Theoretical Issues." Code-Switching in Early English. Ed. Herbert Schendl \& Laura Wright. Berlin \& Boston, MA: De Gruyter Mouton, 2011. 15-44.

Schendl, Herbert \& Laura Wright. eds. Code-Switching in Early English. Berlin \& Boston, MA: De Gruyter Mouton, 2011.

Skutnabb-Kangas, Tove. Bilingualism or Not: The Education of Minorities. Translated by Lars Malmberg \& David Crane. Clevedon, Avon: Multilingual Matters, 1981.

Stammers, Jonathan R. \& Margaret Deuchar. "Testing the Nonce Borrowing Hypothesis. Counterevidence from English-origin Verbs in Welsh.” Bilingualism, Language and Cognition 15.3 (2012): 630-643.

Stenroos, Merja. "Like the Coins when Currencies are Combined: Contextualizing the Written Language of Fifteenth-century English Merchants." Merchants of Innovation: The Language of Traders. Ed. Esther-Miriam Wagner, Bettina Beinhoff \& Ben Outhwaite. Berlin \& Boston, MA: De Gruyter Mouton, 2017. 19-39.

Thomason, Sarah G. Language Contact. Edinburgh: Edinburgh UP, 2001.

Thomason, Sarah G. "Contact as a source of language change." The Handbook of Historical Linguistics. Ed. Brian D. Joseph \& Richard D. Janda. Oxford: Blackwell, 2003. 687-712.

Treffers-Daller, Jeanine. "Towards a Uniform Approach to Code-Switching and Borrowing." ESF Network on Code-Swiching and Language Contact. Papers from the Workshop on Constraints, Conditions and Models. Strasbourg: European Science Foundation, 1991. 259-279.

Winford, Donald. "Contact and Borrowing.” The Handbook of Language Contact. Ed. Raymond Hickey. Oxford \& Malden, MA: Wiley-Blackwell, 2010. 170-187.

Wogan-Browne, Jocelyn. "General Introduction. What's in a Name: The 'French' of 'England'." Language and Culture in Medieval Britain. The French of England c. 1100-c- 1500. Ed. Jocelyn Wogan-Browne, Carolyn Collette, Maryanne Kowaleski, Linne Mooney, Ad Putter \& David Trotter. Woodbridge: Boydell and Brewer, 2009. 1-13. 